\title{
On Overreaching, or Why Rick Perry May Save the Voting Rights Act but Destroy Affirmative Action
}

\author{
Ellen D. Katz
}

\begin{abstract}
The State of Texas is presently staking out two positions that are not typically pursued by a single litigant. On the one hand, Texas is seeking the invalidation of the Voting Rights Act, and, on the other, the State is now defending the validity of the expansive race-based affirmative action policy it uses at its flagship university. This Essay presses the claim that Texas has increased the chance it will lose in both Texas v. Holder and Fisher v. University of Texas because it has opted to stake out markedly extreme positions in each. I argue that Texas would be more likely to succeed had it chosen to temper both its actions and claims in the pending cases. As it stands, Texas's assertive stance in Fisher promises to bolster the aversion many Justices already feel towards affirmative action. With regard to the VRA, however, Texas's uncompromising approach to the regime may prove to be the VRA's best defense. As recent redistricting and voter ID decisions suggest, Texas's stance may be provide what is arguably better evidence for why the statute remains necessary than anything proffered by the VRA's many supporters. Indeed, the State's aggressively hostile stance towards the VRA has the potential to destabilize judicial misgivings about the statute, and, if not fully reverse them, postpone their implementation.
\end{abstract}

\section{INTRODUCTION}

\section{$\mathbf{S}$} UPPORTERS OF RACE-BASED AFFIRMATIVE ACTION tend to think the federal Voting Rights Act (VRA) continues to do important work, while opponents of the VRA generally view affirmative action as obsolete. The State of Texas, however, is presently defying this rule. In Texas $v$. Holder, the State is seeking a declaration that Section 5 of the VRA is unconstitutional, ${ }^{1}$ while, in Fisher v. University of Texas at Austin, Texas is defending the race-based affirmative action policy it uses at its flagship university. ${ }^{2}$ In other words, Texas is positing both a continuing need for state-initiated, racebased affirmative action and the obsolescence of the VRA's race-based structuring of the electoral process.

Ellen D. Katz is a professor of law at the University of Michigan Law School in Ann Arbor, MI.
Texas's stance in these cases is generally viewed as untenable; the State's defense of affirmative action is expected to fail and the challenge to the VRA is thought likely to succeed. ${ }^{3}$ This prediction reflects the widespread belief that judicial antipathy to expansive civil rights enforcement will override refined distinctions regarding the source of regulatory power. ${ }^{4}$ Considerable evidence supports this suspicion, making it possible, and indeed probable,

\footnotetext{
${ }^{1}$ First Amended Expedited Complaint for Declaratory Judgment, Texas v. Holder, Case No 1:12 CV-00128-RMC-DSTRLW, Mar. 12, 2012.

${ }^{2} 132$ S.Ct. 1536 (2012) (granting certiorari); see also Brief in Opposition, 2011 WL 6146835 (Dec. 7, 2011).

${ }^{3}$ See, e.g., Jeffrey Toobin, The Other Big Supreme Court Case, New Yorker, May 1, 2002; Richard L. Hasen, Holder's Voting Rights Gamble, Slate, Dec. 30, 2011.

${ }^{4}$ See generally Ellen D. Katz, Reinforcing Representation: Congressional Power to Enforce the Fourteenth and Fifteenth Amendments in the Rehnquist and Waite Courts, $101 \mathrm{MicH}$. L. ReV. 2341 (2003).
} 
that the realm of permissible civil rights regulation will be considerably smaller once Texas is finished litigating both cases.

In this essay, I explore the possibility of a different outcome. More specifically, I consider the prospect that the courts involved will hold that the Constitution permits Congress to reauthorize the VRA even as it prevents non-remedial, state-initiated, race-based affirmative action of the sort Texas practices at the University of Texas (UT). Put differently, the essay explores the likelihood that Texas has it backwards.

I am not calculating odds here. Nor will I defend the quite defensible contention that congressional power to frame the VRA pursuant to its enforcement powers under the Fourteenth and Fifteenth Amendments exceeds Texas's discretion to craft and implement its state-based affirmative action plan within the confines of the Equal Protection Clause. ${ }^{5}$ Instead, the essay presses the claim that Texas has increased the chance it will lose both cases by opting to stake out markedly extreme positions in each. My claim is that Texas would be more likely to succeed than it now is had it chosen to temper both its actions and claims in the pending cases.

As it stands, Texas's assertive stance in Fisher promises to bolster the aversion many Justices already feel towards affirmative action. ${ }^{6}$ True, the present Supreme Court would be unlikely to look kindly on any race-based admissions plan. Still, the Justices might well have declined review in Fisher had the Texas plan more closely tracked the plan the Court upheld in its 2003 decision, Grutter $v$. Bollinger. ${ }^{7}$ Instead, the plan is, in notable ways, more expansive and aggressive than was the Michigan program, and a lower court decision upholding it attracted the Justices' attention.

In Holder, the State's aggressive stance promises to be consequential as well, but in a different way. The VRA is undeniably vulnerable, with numerous judges having already expressed considerable skepticism about the ongoing need for the statute's regional, remedial provisions. ${ }^{8}$ Still, Texas's uncompromising approach to the regime may prove to be the VRA's best defense. As recent decisions regarding voter ID and redistricting suggest, ${ }^{9}$ Texas's stance provides what is arguably better evidence for why the statute remains necessary than anything proffered by the VRA's many supporters. Indeed, the State's aggressively hostile stance towards the VRA has the potential to destabilize judicial misgivings about the statute, and, if not fully reverse them, postpone their implementation.

Time will tell, of course, whether Texas's strategy will have this effect or instead achieve what the state officials involved hope. But if the VRA should survive the pending challenges, those of us inclined to celebrate should remember to thank Texas for its contribution to the cause. A more measured stance might have easily secured the VRA's invalidation. Aggressively pursuing the statute's demise may prove to be the best hope for its survival.

\section{TESTING LIMITS}

Texas is presently staking out two positions that are not typically pursued by a single litigant. On the one hand, Texas seeks the invalidation of the Voting Rights Act, and, short of that, the adoption of several decidedly narrow constructions of the statute. Meanwhile, the State has adopted and is now defending the validity of the expansive racebased affirmative action policy it uses at its flagship university. Linking these divergent positions is the aggressive way in which they challenge the outer limits of existing doctrine.

\section{A. Constraining the VRA}

Texas decided to challenge the constitutionality of the VRA after the Department of Justice (DOJ) blocked the State from implementing the voter identification law the legislature enacted and Governor Perry signed in 2011. ${ }^{10}$ As a covered jurisdiction under the VRA, Texas must obtain federal approval, known as preclearance, before it can implement any changes to its electoral practices. ${ }^{11}$ Having been rebuffed by DOJ, Texas went to federal court,

\footnotetext{
${ }^{5}$ See, e.g., Bush v. Vera, 517 U.S. 952, 997 (1996) (Kennedy, J., concurring). See also Katz, supra note 4.

${ }^{6}$ See Toobin, supra note 3.

7539 U.S. 306 (2003).

${ }^{8}$ See Northwest Austin Municipal Utility District No. 1 v. Holder, 557 U.S. 193, 202 (2009); id. at 216-229 (Thomas, J., concurring); Riley v. Kennedy, 553 U.S. 406, 492 (Stevens, J., dissenting); Shelby County, Alabama v. Holder, 679 F.3d 848, 885 (D.C.C. 2012) (Williams, J., dissenting).

${ }^{9}$ See Texas v. Holder, 2012 WL 3743676 (D.D.C. Aug. 30, 2012); Texas v. United States, 2012 WL 3671924 (D.D.C. Aug. 28, 2012).

${ }^{10}$ See First Amended Complaint, Texas v. Holder, supra note 1. ${ }^{11} 42$ U.S.C. $\S 1973$.
} 
claiming that its voter ID law is entitled to preclearance under the VRA, and, to the extent that it is not, that the VRA itself is unconstitutional. ${ }^{12}$

The constitutional challenge to the VRA is a familiar one, having been raised both in previous litigation and in other pending cases, one of which is now pending before the Supreme Court. ${ }^{13}$ In brief, it posits that contemporary conditions no longer justify subjecting states to the preclearance requirement, a stringent measure originally enacted a half century ago to address massive African-American disenfranchisement in the Jim Crow South. ${ }^{14}$ Texas makes a claim of this sort in Holder, adding a few flourishes about equal sovereignty, powers reserved to the States and the constitutional guarantee of small " $r$ " republican governance. ${ }^{15}$

As it presses this constitutional argument, however, Texas has also been advancing several exceedingly narrow constructions of its current obligations under the VRA. In 2012 alone, for example, Texas has argued, inter alia, that the VRA permits the State to implement electoral changes that have not been precleared, ${ }^{16}$ without inquiry or regard as to their effect, ${ }^{17}$ and that provide no increase in representational opportunities for a minority population that has vastly increased in size. ${ }^{18}$ These are all extreme positions and all have been rejected in recent federal court rulings. ${ }^{19}$

Consider, first, Texas's claim, pressed earlier this year in Perez v. Perry, ${ }^{20}$ that it should be allowed to implement new districting plans that had yet to be precleared-and about which serious questions had been raised as to their validity. Texas advanced this aggressively narrow reading of the statute after the district court in which it was seeking preclearance announced it would not issue a ruling in time for the 2012 primary elections. ${ }^{21}$ Interim districting plans were needed and a vitriolic fight ensued regarding their content. ${ }^{22}$ By January 2012, Texas was before the Supreme Court telling the Justices that the State's recently enacted redistricting plans should be used as the interim plans, at least until that knotty preclearance process worked its way to closure, ${ }^{23}$ or perhaps was itself declared unconstitutional. ${ }^{24}$

This argument would have done away with one of the VRA's most powerful features in a highly consequential case and perhaps well beyond it. What has long made preclearance not simply an "inventive" 25 remedy but an effective one as well is that it bans implementation of unprecleared changes. This ban displaces the presumption of legitimacy that otherwise attaches to legislative action and places the burden of proof on covered jurisdictions to prove proposed electoral changes are nondiscriminatory before they are implemented. ${ }^{26}$ The goal is to prevent backsliding in the participatory opportunities afforded to minority voters. $^{27}$

Whether or not contemporary conditions continue to justify this burden shifting mechanism is the subject of considerable debate, and the Supreme Court may soon decide that the statute has outlasted the conditions that once justified its imposition. But that question was not directly at issue in Perez when Texas asserted authority to implement unprecleared redistricting plans as interim plans. That is, the State's argument threatened to render the statute a

${ }^{12}$ See First Amended Complaint, Texas v. Holder, supra note 1.

${ }^{13}$ See, e.g., Shelby County, Alabama v. Holder, 679 F.3d 848 (D.C. Cir. 2012) cert. granted 2012 WL 3018430 (Nov. 9, 2012); LaRoque v. Holder, 679 F.3d 905 (D.C. Cir. 2011); Northwest Austin Municipal Utility District No. 1 v. Holder, 557 U.S. 193 (2009).

${ }^{14}$ See, e.g., Brief for Appellant, Shelby County v. Holder, 2011 WL 6282146 (C.A.D.C.).

${ }^{15}$ See First Amended Complaint, Texas v. Holder, supra note 1, at Parts D, E, and F.

${ }^{16}$ See infra notes $20-29$ and accompanying text.

${ }^{17}$ See infra notes 30-36 and accompanying text.

${ }^{18}$ See infra notes 37-48 and accompanying text.

${ }^{19}$ See Perez v. Perry, 132 S. Ct. 934 (2012); Texas v. Holder, 2012 WL 3743676 (D.D.C. Aug. 30, 2012); Texas v. United States, 2012 WL 3671924 (D.D.C. Aug. 28, 2012).

${ }^{20} 132$ S. Ct. 934 (2012).

${ }^{21}$ See id. at 940.

${ }^{22}$ TeX. Redistricting, $<$ http://txredistricting.org $>$ (last visited May 10,2012) (collecting a number of documents, including briefs, court opinions, and statements by government officials, relating to redistricting in Texas, many of which note misconduct and bad faith on the part of many involved parties).

${ }^{23}$ See Brief for Appellant, State of Texas, Perry v. Perez, 2011 WL 6468711 (U.S.) (Appellate Brief) (Dec. 21, 2011).

${ }^{24}$ See Shelby County, Alabama v. Holder, 679 F.3d 848 (D.C. Cir. 2012), cert. granted 2012 WL 3018430 (Nov. 9, 2012).

${ }^{25}$ See South Carolina v. Katzenbach, 383 U.S. 301, 327 (1966). ${ }^{26}$ See S. Rep. No. 97-417, at 6, reprinted in 1982 U.S. Code Cong. \& Ad. News 177, 183 (1982) ("The effectiveness of section 5 rests in part on the fact that a submitting jurisdiction bears the burden of showing that a proposed modification is not discriminatory in purpose or effect.”).

${ }^{27}$ See, e.g., South Carolina v. Katzenbach, 383 U.S. at 328 (preclearance regime is meant to "shift the advantage of time and inertia from the perpetrators of the evil to its victims"); see also Reno v. Bossier Parish, 528 U.S. 320, 366 (2000) (Souter, J,. dissenting) (noting regime's purpose to prevent covered jurisdictions from "pour[ing] old poison into new bottles"). 
nullity, without a constitutional decision so holding, and in the context of an expedited, interlocutory ruling in a messy, discursively-briefed case. ${ }^{28}$ The Justices seemed to recognize the sweeping nature of what Texas was seeking, both by making explicit at oral argument that "the constitutionality of Section 5 was not at issue," and by denying Texas the authority it sought to implement its districting plans precisely as enacted. ${ }^{29}$

Texas's aggressive stance towards the VRA has also met resistance in the lower federal courts. In August 2012, a three-judge panel flatly rejected Texas's claim that its new voter ID is VRA compliant, while a separate three-judge panel agreed with DOJ that several of the State's new redistricting plans should not be precleared.

The voter ID case is Texas v. Holder, in which the State is also pressing the claim that the VRA is unconstitutional. The recent ruling is limited to the State's statutory claims, and specifically, Texas's argument that DOJ erred both in finding the State's voter ID measure would make voting more difficult for minority voters in Texas, ${ }^{30}$ and in thinking that such an impact, were it to exist, would be grounds to block implementation of the voter ID measure. According to Texas, the VRA's discriminatory effects prong should not apply to measures like voter ID, ${ }^{31}$ and such measures should be implemented absent evidence they were enacted with racially discriminatory intent. ${ }^{32}$

The lower court ruling rejected these claims. Finding "everything Texas has submitted as affirmative evidence [to be] unpersuasive, invalid, or both," 33 the panel concluded that Texas failed to establish that its voter ID measure is nondiscriminatory in effect, which in this context means the measure does not cause retrogression, or make things worse, for minority voters. The panel, moreover, emphasized that the problem was not simply the State's inability to "prove a negative," but also the fact that "uncontested record evidence conclusively shows that the implicit costs of obtaining SB 14-qualifying ID will fall most heavily on the poor and that a disproportionately high percentage of African-Americans and Hispanics in Texas live in poverty." 34

The federal court was even less impressed with Texas's "primary" claim, namely, that the voter ID should be precleared absent evidence it was enacted "on account of" or "because" of the race of those it targets. Calling this argument "entirely unpersuasive," the panel said that it ignored the history that prompted enactment of the VRA in the first instance, Congress's explicit intent, the statute's plain language, and decades of precedent interpreting it. ${ }^{35}$ Indeed, the panel said the idea that voter ID might be immune from discriminatory effects analysis "completely misses the point of section 5." 36

That ruling issued just two days after a separate three-judge panel decision in Texas v. United States, which concluded that Texas's new redistricting plans are not entitled to preclearance. From the start, this dispute has focused on whether the State has drawn a sufficient number of districts in which minority voters exercise controlling influence. The VRA has long been read to require that, under certain conditions, minority voters be concentrated in particular electoral districts so that they are able to elect representatives of choice. ${ }^{37}$ Texas did not directly contest this controversial requirement, but instead, insisted that the new districting plans provided minority voters all that they are entitled to receive under the statute.

The dispute is a complex one, involving multiple parties and claims addressing three separate districting plans. For present purposes, however, it is sufficient to consider one contested issue: namely, whether, under the VRA, Texas's new congressional districting plan must include more districts in which

\footnotetext{
${ }^{28}$ See Texas Goes Big-Asks for Legislature's Maps to Be Used in 2012 Elections, Citing Tight Schedule, $<$ http://txredistricting .org/post/14579141904/texas-goes-big-asks-for-legislatur $>$.

${ }^{29}$ See Perry v. Perez, 132 S. Ct. 934 (2012); but cf. Richard Hasen, Breaking News: Supreme Court Decides Texas Redistricting Case, Reverses Lower Court, Election L. Blog (Jan. 20, 2012, 7:25AM), <http://electionlawblog.org/?p=28312> (describing decision as a "big win" for Texas).

${ }^{30}$ See Letter, Tom Perez, Assistant Attorney General for Civil Rights, to Keith Ingram, Director of Elections, Elections Divisions, Office of the Texas Secretary of State, Mar. 12, 2012 (stating that Latino voters comprise a disproportionate share of the more than 600,000 (or, perhaps, far more) voters believed to lack the identification the new law requires; that they face distinct obstacles obtaining the identification cards issued by the State's Department of Public Safety; and that Texas had failed to enact even rudimentary measures that would educate these voters about the ID requirement and otherwise foster compliance with it).

${ }^{31}$ See First Amended Complaint, Texas v. Holder, supra note 1. ${ }^{32}$ See id.

${ }^{33}$ Texas v. Holder, 2012 WL 3743676 (D.D.C.) Aug. 30, 2012, at $* 26$.

${ }^{34} I d$. at $* 30$.

${ }^{35} I d$. at $* 33$.

${ }^{36} I d$. at $* 10$.

${ }^{37}$ See, e.g., Thornburg v. Gingles, 478 U.S. 30 (1986).
} 
Latino voters enjoy controlling influence than did the prior plan. Texas has argued that the VRA requires only that the new plan contain the same number of "safe" Latino districts as did the prior plan, and that it does not require the State to increase that number. ${ }^{38}$

What makes this claim both controversial and aggressive is that the population of Texas has grown substantially since the State adopted the last set of districting plans, and most of that growth occurred in the Latino community. ${ }^{39}$ Indeed, Texas might well have lost a congressional seat, rather than gained four, absent the growth in the State's Latino population. ${ }^{40}$ Texas nevertheless maintains that the VRA requires that the State do nothing more than maintain, and pointedly, not reduce, the number of Latino ability districts.

There is authority supporting this proposition. The VRA is explicit that it provides no right to proportional representation, and precedent makes clear that the statute does not require that covered states mechanically add minority-controlled seats each time population shifts increase the size of their congressional delegation. ${ }^{41}$ Fifteen years ago, for example, the Court upheld a redistricting plan from Georgia that provided a single district in which African-American voters were a majority, where the prior plan also had had only one such district. While the additional congressional seat Georgia had been awarded in the interim meant black voters had proportionally less influence under the new plan, Abrams v. Johnson held that the VRA's ban on retrogression required that States maintain only the absolute, rather than proportional, number of minority opportunity districts. ${ }^{42}$

Texas relied heavily on the Georgia case and argued that the disputed districting plans are VRA compliant, and Abrams v. Johnson is why the district court initially concluded on summary judgment that the Texas plans were not retrogressive in effect under the VRA. ${ }^{43}$ Still, the court observed that Georgia had not experienced the sort of population growth Texas has seen, and whatever the VRA mandate is with regard to practices that have discriminatory effects, Texas's refusal to provide Latino voters any increase in their proportional share of representational opportunities under contemporary conditions raises a serious question of discriminatory intent. ${ }^{44}$

The three-judge panel in Texas $v$. United States unanimously held that the congressional plan had, in fact, been enacted with discriminatory intent, and that the plan turned out to be discriminatory in effect as well. ${ }^{45}$ On the latter point, the court said that the arguments presented at trial left it convinced that Texas's failure to include a new minority district among the four new districts in the enacted plan made it retrogressive under the specific facts of this case. ${ }^{46}$

Standing alone, that finding meant the congressional plan was not entitled to preclearance, but the panel nevertheless proceeded to find that the plan had been enacted with discriminatory intent as well. The panel observed that state officials had "consciously" replaced active Latino voters in an ability district with low turnout ones, in order "to reduce" Latino influence "without making it look like anything...had changed"; that officials removed critical economic centers and the incumbents' district offices from three African-American districts, while performing no comparable "surgery" on Anglo districts; that state officials excluded Latino and African-American congressional representatives from the drafting process, even though they solicited and implemented the preferences of Anglo members of Congress; and that the State offered little opportunity for public review and challenge to the plan. ${ }^{47}$

Texas attributed these disputed moves and process irregularities to "coincidence" and perhaps "blithe indifference" to minority interests, as opposed to discriminatory intent. The court, however, deemed these explanations "not credible"

\footnotetext{
${ }^{38}$ See Texas v. United States, 831 F. Supp. 2d 244 (D.D.C. 2011).

${ }^{39}$ See id. at 268.

${ }^{40} \mathrm{Id}$.

${ }^{41}$ See, e.g., Abrams v. Johnson, 521 U.S. 74 (1997); Bush v. Vera 517 U.S. 952 (1996).

${ }^{42}$ Abrams, 521 U.S. at $97-98$ (rejecting the notion that "each time a State with a majority-minority district [is] allowed to add one new district because of population growth, it would have to be majority-minority" as something "the Voting Rights Act does not require").

${ }^{43} 831$ F. Supp. $2 \mathrm{~d}$ at 269.

${ }^{44} I d$.

${ }^{45}$ Texas v. United States, 2012 WL 3671924 (D.D.C. Aug. 28, 2012).

${ }^{46}$ More specifically, the panel found that, while the VRA does not guarantee proportional representation, Texas's failure to create a Latino ability district among the four new congressional seats it was awarded significantly increased the prior plan's representation gap, a reference to the difference between what proportional representation would yield and number of districts actually drawn. The panel pointed out that no comparable increase occurred in Georgia on the facts of Abrams. Id. at *18. ${ }^{47} I d$. at $* 18 * 21$.
} 
and instead found itself "persuaded by the totality of the evidence that the plan was enacted with discriminatory intent." 48

Consider whether this ruling would have issued had Texas opted to provide Latino voters controlling influence in just one of the new congressional districts it had been awarded. To be sure, such a move would not have enabled Texas to avoid the litigation it has faced since adopting its redistricting plans. Still, the move might have signaled to the district court (and, perhaps, beyond) that the Latino community is able to exert a degree of influence through the political process that the preclearance process itself assumes is generally lacking. Had Texas provided Latino voters controlling influence in just one additional district, it would have signaled its recognition that the Latino community should share at least some of the benefits its population growth has brought to the State. As it stands, Texas opted to give the Latino population nothing, a move the federal district court found to violate the VRA and involve the sort of intentional discrimination Texas insists no longer occurs.

\section{B. Expanding affirmative action}

As Texas has been pressing aggressively narrow constructions of the VRA, it is also pursuing an aggressively expansive vision of what constitutes permissible affirmative action under Grutter $v$. Bollinger. Without doubt, all race-based affirmative action plans are vulnerable in the present Court, which has lacked a majority supporting Grutter since Justice O'Connor retired in 2005. But it is the way in which the program at issue in Fisher differs from the Michigan plan that makes it particularly susceptible to invalidation. Indeed, most of Abigail Fisher's petition to the Supreme Court focused on the ways in which UT's program goes beyond the boundaries of what Grutter had deemed permissible. ${ }^{49}$

In particular, two aspects of the Texas program are notably more expansive than was Michigan's. The first is the targeted way UT administrators use racial criteria to promote racial diversity not only in the entering class, but also at the classroom and program level; the second is the University's decision to use Grutter's "holistic review" in conjunction with its $10 \%$ plan, under which UT guarantees admissions to all students who graduate in the top $10 \%$ of their high school class. ${ }^{50}$ Both aspects of the Texas program raised concerns in the lower courts.
A solid argument exists that the benefits of diversity identified in Grutter require extending some affirmative action efforts to the classroom and program level. Still, the means by which such diversity is achieved involves targeted racial moves of a sort likely to displease a majority of the Roberts Court. ${ }^{51}$ Indeed, most Justices on the present Court are openly hostile to, or, at least deeply discomforted by, the rigid use of race. Three explicitly dissented in Grutter ${ }^{52}$ and five objected in Parents Involved in Community Schools v. Seattle School Dist. No. 1, which struck down programs that relied on race-based student assignments to foster diversity and avoid what school administrators' called "racial isolation." ${ }^{53}$ Given these opinions and the charges of unconstitutional racial balancing they lodged, one can easily envision an opinion striking down UT's effort to achieve classroom level diversity as requiring impermissible racial balancing.

So too, Texas's decision to employ Grutterstyled "holistic" review in conjunction with its $10 \%$ plan represents an expansive approach to the prior precedent. Here, the expansiveness of what Texas is doing lies not in the arguable rigidity with which the State is using racial criteria, but instead with its insistence that it needs to use race at all. True, Texas has a solid argument that, standing alone, the $10 \%$ plan offers an inadequate substitute for the flexibility and individualized attention promised by Grutter's holistic rule. And yet, the fact that UT admits a greater proportion of minority students under the $10 \%$ plan than outside of it will fuel concern that Texas's use of race beyond the $10 \%$ plan is not absolutely necessary to achieve the diversity of the sort Grutter protects. ${ }^{54}$

\footnotetext{
${ }^{48} I d$. at $* 21$.

${ }^{49}$ See Petition for Writ of Certiorari, Fisher v. University of Texas at Austin, 2011 WL 4352286 (U.S.) (Sept. 15, 2011).

${ }^{50}$ See Fisher v. University of Texas at Austin, 644 F.3d 301 (5th Cir. 2011) (Jones, J., dissenting from the denial of the petition for rehearing en banc); Fisher v. University of Texas at Austin, 631 F.3d 213 (5th Cir. 2011) (Garza, J., specially concurring).

${ }^{51}$ See, e.g., Parents Involved in Community Schools v. Seattle School Dist. No. 1, 551U.S. 701 (2007).

${ }^{52} 539$ U.S. 306, 347 (Scalia, J., dissenting); id. at 349 (Justice Thomas, dissenting); id. at 378 (Rehnquist, C.J., with whom Justices Scalia, Kennedy and Thomas join, dissenting); id. at 387 (Kennedy, J., dissenting).

${ }^{53} 551$ U.S. 701.

${ }^{54}$ See Fisher v. University of Texas at Austin, 644 F.3d 301 (5th Cir. 2011) (Jones, J., dissenting from the denial of the petition for rehearing en banc); Fisher v. University of Texas at Austin, 631 F.3d 213 (5th Cir. 2011) (Garza, J., specially concurring).
} 
Back in Parents Involved, Justice Kennedy's critical concurring opinion complained that the school districts' race-based policies did little to foster the diversity school administrators sought. ${ }^{55}$ In Fisher, a similar complaint is easily anticipated. If the facially race-neutral $10 \%$ plan more effectively fosters diversity than an overtly race-conscious one, why not rely on, or, if necessary, expand the former instead of employing less effective racial criteria to achieve the same purpose? To be sure, good cause may exist to use a more targeted approach to locate students for programs in which diversity is manifestly lacking and remains lacking under the $10 \%$ plans. Still, using the programs in conjunction with one another has, not unexpectedly, given rise to charges questioning their necessity.

\section{WHY LESS IS MORE}

Texas is widely expected to lose in Fisher while the constitutional claim it is pressing in Holder is thought likely to prevail either in Holder itself or, more likely, in the case now pending before the Supreme Court. ${ }^{56}$ These expectations rest less on the particular details of the Texas cases than on well-founded perceptions about judicial antipathy to race-based programs like affirmative action and statutes like the VRA. No one should be surprised if both affirmative action and the VRA fail to survive the pending cases.

I nevertheless think that Texas would be more likely to succeed with both claims than it now is had it opted to press less expansive and aggressive positions in each. This suggestion, to be sure, is both speculative and non-falsifiable (unless, of course, the Court in its decision were to say so, which it won't). To support my speculation, I will briefly discuss some other cases in which I think the outcomes hinged on the aggressive way a crucial party pushed the limits of existing doctrine. But this reading of precedent is similarly speculative, and, accordingly, my suggestion regarding the Texas cases remains just that, namely, a suggestion. My interest, however, is not in presenting scientific proof, but instead to invite consideration of the ways in which pushing for less may ultimately be a better way to achieve more.

Consider the example the Supreme Court set a half-century ago when it decided to enter the famed "political thicket" and address the rampant mal-apportionment that then characterized American elections. That foray yielded the one-person, one-vote doctrine, a principle that is now so ingrained as constitutional truth that students today often have difficulty grasping what made it once controversial or why it should still be so understood. And yet, the Court's decisions to entertain the challenge in 1962 and thereafter to endorse equal apportionment were hardly preordained. Not all that long before Baker v. Carr, a majority of the Justices seemed adamant that they would not get involved. ${ }^{57}$

But then the Alabama legislature voted to place all but four of Tuskegee's African-American residents outside city limits. The legislation changing the city's boundaries issued shortly after an African-American administrator at the renowned Tuskegee Institute nearly won a seat on the city's school board in a town that had been majority black (at least before the Alabama legislature got to work on it) and in which literacy tests were proving increasingly ineffective means to disenfranchise a highly-educated African-American population. ${ }^{58}$ Alabama's purpose in drawing the new, tortuous boundaries was clear, even absent any explicit statement as to its intent. At the time, moreover, Alabama's action appeared permissible, or at least immune from challenge, given the Justices' voiced disinterest in reviewing municipal or electoral boundaries.

Gomillion v. Lightfoot nevertheless struck down the Alabama law. The ruling's Fifteenth Amendment focus was likely designed to limit the decision's reach, but in many senses, Gomillion opened the door for the Court to reconsider its hands-off approach to questions of apportionment more generally. ${ }^{59}$ Two years later, Baker v. Carr announced the Court was willing to consider whether the Constitution might be violated by a Tennessee apportionment plan that allotted an urban district ten times the population of a rural one. ${ }^{60}$ Reynolds $v$. Sims followed quickly, if not

\footnotetext{
${ }^{55} 551$ U.S. at $783-88$.

${ }^{56}$ See supra note 13.

${ }^{57}$ See Colegrove v. Green, 328 U.S. 549 (1946).

${ }^{58}$ See generally Bernard TAPER, GOMILLION Versus Lightfoot: The Right to Vote in Apartheid Alabama (2003).

${ }^{59}$ See, e.g., Bernard Grofman, Controversies in Minority

Voting: The Voting Rights Act in Perspective 165 (1992).

${ }^{60} 369$ U.S. 186 (1962).
} 
inexorably, from Baker and announced the one-person, one-vote principle. ${ }^{61}$

In the years since, the Court has applied that principle relentlessly, and, some might say, absurdly. The 1983 decision Karcher v. Daggett ${ }^{62}$ notoriously found a one-person, one-vote violation in a redistricting plan with a population deviation smaller than the census undercount, and, more recently, a federal district court in Pennsylvania struck down a state-wide districting plan for a nineteen-person deviation. ${ }^{63}$ Whatever the wisdom in such holdings, I suspect that foundational decisions like Baker and Reynolds (and indeed Gomillion before them) would never have issued had they involved only nominal deviations or population shifts. That is, it was the extreme population deviation disputed in Baker and Reynolds, and the removal of virtually every African-American resident from Tuskegee that propelled the Justices to act.

On one view, of course, this need not have been the case. Insofar as questions of districting and apportionment are "political" questions that federal judges purportedly lack competency to assess, legislators should have enjoyed carte blanche to draw (or let stand) the lines as they saw fit, subject only to such retribution as voters remained capable of expressing through the political process. Put differently, as a matter of doctrine, extreme population deviations should have raised no more concern-at least in federal court-than minute ones. So too, denying scores of black residents their "pre-existing municipal vote" ${ }^{64}$ should have been no more objectionable than denying that vote to just a few of them.

As it happened, attorneys in both cases were asked about precisely this point, and these lawyers insisted that their claims would be no different had the state action involved been less extreme. In fact, plaintiff's counsel in Baker readily acknowledged his intention to challenge any population deviation, not only the extreme ones. ${ }^{65}$ Similarly, Charles Gomillion's lawyer, Fred Gray, insisted the constitutional violation in the case lay in the removal of African-American residents based on their race, not in the number of residents removed. ${ }^{66}$

And yet, I doubt that Gomillion, Baker, and Reynolds would have been decided as they were had the underlying state action involved less extreme conduct and thus had less aggressively challenged the limits of existing doctrine. It was the magnitude of that action (or extreme consequences of inaction) that ultimately swayed a majority of the Court to get involved. Had the apportionment scheme in Baker fallen short of equality by some less egregious degree, or if Tuskegee's new municipal boundaries eliminated significantly fewer African-American residents, the Justices might well have stayed out of the fray. In other words, had the state officials exercised their discretion less aggressively, they might have retained more of the discretion they sought.

That is not to suggest that gross mal-apportionment would have persisted indefinitely, or that exiling a municipality's minority population would still be permissible so long as a nontrivial number of residents remain within city limits. Doctrine would have certainly developed, but both the path and substance of that development would likely have been different, and the pivotal moments other than the ones we had, had the state officials involved opted to temper the discretion they exercised.

The same is true in other contexts. The Rehnquist Court, for instance, might never have intervened in Shaw v. Reno and its progeny absent its conviction that the public officials involved had exercised their discretion too aggressively and pushed the limits of existing doctrine too far. ${ }^{67}$ Before the Justices got involved in these cases, state officials had routinely considered race, among other factors, when drawing district lines. The only doctrinal constraint was that resulting districts were not to cause racial vote dilution within the meaning of the Constitution or the Voting Rights Act. ${ }^{68}$

The round of redistricting that followed the 1990 census, however, yielded a host of intricate, oddly shaped, racially informed districts that were produced, at least in part, because the Department of Justice had insisted that particular states increase participatory opportunities for minority voters.

\footnotetext{
61377 U.S. 533 (1964).

${ }^{62} 462$ U.S. 725 (1983)

${ }^{63}$ See Vieth v. Pennsylvania, 188 F. Supp. 2d 532 (M.D. Pa. 2002).

${ }^{64}$ Gomillion v. Lightfoot, 364 U.S. at 341

${ }^{65} \mathrm{See}$ Stephen Ansolabehere and Samuel Issacharoff, The Story of Baker v. Carr, in Constitutional Law Stories 271 (Michael Dorf, ed. 2d ed. 2009).

${ }^{66}$ See Samuel Issacharoff, et al., The Law of Democracy (4th ed. 2012).

${ }^{67}$ See, e.g., Hunt v. Cromartie, 526 U.S. 541 (1999); Bush v. Vera, 517 U.S. 952 (1996); Miller v. Johnson, 515 U.S. 900 (1995); Shaw v. Reno, 509 U.S. 630 (1993).

${ }^{68}$ See United Jewish Organizations of Williamsburgh, Inc. v. Carey, 430 U.S. 144 (1977); White v. Regester, 412 U.S. 755 (1973).
} 
The Court became convinced that DOJ was unyieldingly seeking the creation of black majorityminority districts wherever possible. ${ }^{69}$ To curb this behavior, the Justices identified a new, analytically distinct injury under the Equal Protection Clause stemming from the excessive use of race in the districting process absent compelling justification. ${ }^{70}$

The Court struggled with the Shaw doctrine throughout the 1990s, with many observers and even some of the Justices condemning it as unworkable and incoherent. ${ }^{71}$ Closure came somewhat unexpectedly with the Court's decision in Hunt v. Cromartie, a much criticized holding that nevertheless offered what came to be seen as a roadmap for avoiding liability under Shaw. ${ }^{72}$ Tone down references to race, Cromartie suggested, and liability under Shaw could be avoided. ${ }^{73}$

That admonition is, for present purposes, what distinguishes Shaw and its progeny from Baker and Reynolds. While one-person, one-vote eliminated entirely the discretion that had produced vast population disparities between districts, the Shaw injury evolved so as to map precisely onto the very conduct that prompted the Court to identify an injury in the first place. Notably, the Shaw doctrine does not excise race from the districting process. Moreover, in stark contrast to other contexts in which race is considered, Shaw does not subject districting decisions that rely on race to strict scrutiny. Instead, it is only the excessive, or predominant, use of race that triggers exacting review, ${ }^{74}$ just as it was the excessive use of race (or the perception of such use), that first convinced the Court something was awry in the redistricting process. The doctrinal rule in Shaw circumscribed but ultimately preserved a degree of discretion by those it regulates. Reynolds eliminated discretion entirely. It is, in particular, this latter move that I want to focus on here.

More specifically, when does the aggressive exercise of discretion backfire and lawful discretion get pressed so far that discretion is subsequently eliminated? A gratuitous assertion of authority to ban books propelled the Court in Citizens United v. Federal Election Commission to eliminate entirely the basis for both the regulatory conduct actually in dispute and the discretion the agency imagined itself authorized to exercise. ${ }^{75}$ And yet, a perceived failure of deliberation, and hence discretion poorly exercised, on the part of Congress led the Court in Northwest Austin Municipal Utility District No. 1 v. Holder to find a statutory amendment that had not previously existed, and thereby sidestep, albeit, not for long a looming, constitutional question and the exercise of congressional discretion it implicates. ${ }^{76}$

It is, of course, this constitutional question that is now pending before the Supreme Court. It also is the question Texas is pursuing in Holder, alongside several aggressively narrow constructions of the VRA and a decidedly expansive view of affirmative action. These varied positions are all controversial and the persuasiveness of the arguments marshaled in their support hinges largely on the degree to which one already admires or dislikes the VRA and affirmative action. Still, their resolution is also sure to be shaped by the aggressive stance Texas is pursuing in these cases.

In Fisher, there are solid-perhaps even persuasive-arguments that support crafting an affirmative action plan the way Texas has done at UT. Still, a program that more closely tracked the Michigan Law plan upheld in Grutter would be less vulnerable today. True, the Court's aversion to affirmative action may be such that no race-based plan, even one far more limited than Texas's, would be able to dodge, much less survive, scrutiny. And yet, the Justices might well have opted against review had Texas crafted a plan that mirrored - rather than expanded upon - the plan Grutter so narrowly upheld.

In Holder, Texas's claim that the VRA is both obsolete and unconstitutional seeks to operationalize a view Governor Perry expressed during his short-lived bid for the Republican Party's presidential nomination. ${ }^{77}$ Candidates for federal office have, at least in recent years, shied away from condemning the "crown jewel" of the civil rights movement, ${ }^{78}$ but Governor Perry is not alone in

\footnotetext{
${ }^{69}$ See Peter J. Rubin, Reconnecting Doctrine and Purpose: A Comprehensive Approach to Strict Scrutiny After Adarand and Shaw, 149 U. PA. L. Rev. 1, 105-06 (2000).

${ }^{70}$ See Miller v. Johnson, 515 U.S. 900 (1995).

${ }^{71}$ See IsSACHAROFF, supra note 66.

${ }^{72} I d$.

${ }^{73} \mathrm{Id}$.

${ }^{74}$ See, e.g., John Hart Ely, Confounded by Cromartie: Are Racial Stereotypes Now Acceptable Across the Board or Only When Used in Support of Partisan Gerrymanders?, 56 U. Miami L. ReV. 489 (2002).

75130 S. Ct. 876 (2010)

${ }^{76} 557$ U.S. 193 (2009).

${ }^{77}<$ http://video.foxnews.com/v/1395805419001/perry-southcarolina-is-at-war-with-federal-government $>$.

${ }^{78}$ See, e.g., Pres. Ronald Reagan, Remarks on Signing the Voting Rights Act Amendments of 1982 (June 29, 1982), available at <http://www.reagan.utexas.edu/archives/speeches/1982/ 62982b.htm >.
} 
thinking the VRA invalid, and a number of credible arguments support that position.

The claim, however, is not strengthened by Texas's decision to couple it with a series of aggressively narrow constructions of the statute. True, such constructions might facially seem compatible with a constitutional challenge. After all, why endure, much less endorse, broad applications of a statutory regime a litigant believes to be invalid, particularly when more narrow constructions offer reviewing courts the means to limit the regime's reach absent a constitutional holding? ${ }^{79}$

This stance, however, becomes deeply problematic when the statute at issue is the VRA. The VRA's regional provisions rest on the premise that the political processes in covered jurisdictions would not be open, accessible, and responsive to the interests of protected minority groups absent the oversight the statute provides. While opponents of the VRA vigorously contest this premise, Texas has done a good deal to bolster that claim through both the miserly readings of the VRA it has recently pressed and the conduct those readings seek to validate.

More specifically, the contention that minority voters in Texas can adequately fend for themselves in the political process is undercut by Texas's insistence that its new voter ID law is nondiscriminatory within the meaning of the VRA. As the lower federal court noted in Texas v. Holder, Texas failed to supplement the new ID requirement with measures relating to education and access that might have eased the disproportionate burden the new law places on African-American and Latino voters. ${ }^{80}$ What's more, the State coupled that failure with its insistence that the measure's racially disparate impact is neither part of the discrimination banned by the VRA nor, apparently, a cause for concern among state officials.

So too, the notion that political processes are open, accessible, and responsive to minority voters is severely challenged by Texas's insistence that the new districting plans need not provide the Latino community any additional influence over what it previously had, despite the massive growth in that community's size and the four new congressional seats Texas received as a direct result of that growth. True, Texas's position finds some support in precedent, ${ }^{81}$ and undoubtedly seeks to tap into judicial dissatisfaction with the VRA's group-based mandates. And yet, the notion that the Latino voters should get none of the benefits-indeed, the spoils- that they enabled the State to receive challenges the notion that local political processes are responsive to Latino interests.

That is not to say that Texas needed to provide Latino voters controlling influence in all the new seats, or even half of them. But by opting to deny them control in any-the "inexorable zero," so to speak-Texas comes close to making the case it is ostensibly seeking to refute. Including just one additional Latino-controlled congressional seat would not have blocked the litigation in which Texas has now long been mired, but it would have changed its tenor considerably and perhaps led to a very different outcome than one reached by the lower court in Texas $v$. United States.

The same is true with respect to voter ID. Texas might have chosen to craft a very different voter ID measure, one far more likely to have survived scrutiny under the VRA. As it stands, the federal court decision in Texas v. Holder described the Texas provision's "strict, unforgiving burdens" and called it "the most stringent in the country." 82 The panel, moreover, emphasized that Texas "ignor[ed] warnings" about the ways in which the voter ID requirement burdened both the poor and racial minorities, and explicitly refused to craft the requirement in ways that might mitigate those burdens. Adopting such mitigating measures, the panel suggested, "could have made this a far closer case." 83

Ultimately, Texas's miserly readings of its obligations under the VRA and the actions it seeks to vindicate through those readings may prove to be the best evidence for why the statute remains necessary. Whether the State's aggressively hostile stance towards the VRA destabilizes judicial misgivings about the statute remains to be seen. But that prospect looks more plausible today than it once did precisely because Texas has opted to take such an antagonistic approach towards the statute it seeks to dismantle.

\footnotetext{
${ }^{79}$ See generally, Ashwander v. Tennessee Valley Authority, 297 U.S. 288 (1936).

${ }^{80}$ See Letter, Tom Perez, Assistant Attorney General for Civil Rights, to Keith Ingram, Director of Elections, Elections Divisions, Office of the Texas Secretary of State, Mar. 12, 2012.

${ }^{81}$ See supra notes and accompanying text.

${ }^{82}$ Texas v. Holder, 2012 WL 3743676 , at $* 32$.

${ }^{83} I d$.
} 


\section{CONCLUSION}

The most interesting cases, and the ones most fun to teach, are often those in which the outcome, or a critical step in the chain of reasoning, seems inordinately sweeping or unduly intrusive or simply unexpected. What makes such cases interesting, and fodder for good discussions, is that they invite us to look beyond the text of an opinion to understand what is going on. The text by itself is inadequate explanation, and, hence, we must speculate. Therein lies the fun. Typically, there are multiple, plausible explanations; some are competing, others co-existing, and, typically, none is demonstrably right. A suspicion the decision is outcome driven invariably surfaces, and yet, that preferred result is frequently obtainable without the sweeping or even troublesome moves used to bring it about.

A distinct explanation, however, may best capture a host of these decisions. Namely, judges are apt to rule in unexpected and expansive ways when reviewing decisions they perceive to overreach and to press lawful discretion too far. In fact, judges are wont to respond to overreaching by overreaching themselves. They are typically fully aware that they are doing so and convinced that doing so is the most responsible stance given the circumstances.

None of this means that conduct challenging the limits of established discretion is always ill-advised. Some such moves will evade review or wind up passing muster, thereby expanding the discretionary realm and perhaps attracting a mild admonition to be mindful of boundaries in the future. ${ }^{84}$ Other conduct challenging the limits of the permissible will be invalidated but with narrow rulings that reaffirm or more carefully demarcate the boundaries restricting the lawful exercise of discretion. But there also are those cases in which disputed conduct presses lawful discretion so far that the discretion at issue gets eliminated entirely.
The aggressive stance Texas has taken with regard to both the VRA and affirmative action risks falling into this latter category. In Fisher, the State's approach is likely to fuel the disdain many Justices have already voiced regarding affirmative action. ${ }^{85}$ In Holder, by contrast, the State's stance may-and indeed should—challenge existing judicial misgivings about the statute.

The Roberts Court has already voiced considerable skepticism about the ongoing need for the VRA's regional, remedial provisions, ${ }^{86}$ and the Justices appear poised to strike down a regime long viewed as a significant but necessary constraint on local discretion. Texas's uncompromising approach to the regime, and the recent federal court decisions condemning it, may slow their momentum. The conduct the State has sought to validate through it aggressively narrow readings of the VRA raises serious doubts as to whether Texas has secured the conditions it insists exist and render the VRA obsolete.

It is possible, of course, that Texas may yet benefit from appellate rulings that deem its conduct to be VRA compliant, or ones that instruct the State to take some modest steps that would secure such compliance. So too, no one should be surprised if the State winds up party to, or simply partaking in, a ruling that invalidates the statute in its entirety. But should the Roberts Court defy expectations and conclude that the VRA is still doing important work, I think Texas will be largely responsible. Had the State pushed for less, it would stand a better chance of securing more of the discretion it professes to seek.

Address correspondence to: Ellen D. Katz University of Michigan Law School 625 South State Street Ann Arbor, Michigan 48109-1215

E-mail: ekatz@umich.edu

\footnotetext{
${ }^{84}$ See generally Nixon v. United States, 506 U.S. 224, 253-4 (1993) (Souter, J., concurring) (agreeing case presented a non-justiciable political question, while noting that "judicial interference might well be appropriate" were the Senate "to act in a manner seriously threatening the integrity of its results").

${ }^{85}$ See supra notes $51-53,55$ and accompanying text.

${ }^{86}$ See Northwest Austin Municipal Utility District No. 1 v. Holder, 557 U.S. 193 (2009).
} 